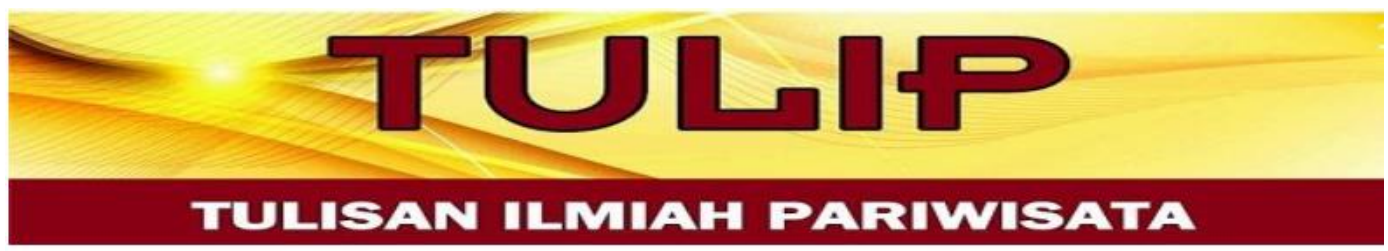

\title{
IMPELEMENTASI KEBIJAKAN PEMERINTAH DAERAH KAB. GORONTALO UTARA TERHADAP WISATA BUDAYA RITUAL MANDI SAFAR
}

\author{
Febrianto Hakeu, Sri Sunarti \\ febriantohakeu@umgo.ac.id, Srisunarti@umgo.ac.id \\ FIB UMGo, Jl. Prof Mansoer Pateda, Indonesia
}

\begin{abstract}
This article aims to determine the Shafar Bathing Ritual Process in Kec. Atinggola Buata Village, North Gorontalo Regency, and knowing the Implementation of Regional Government Policies in the Cultural Tourism sector towards Shafar Bathing Rituals in North Gorontalo District, and formulating solutions to the identified constraints. This article is analyzed based on a descriptive qualitative approach. The results of the analysis of this article are 1) Shafar's bathing ritual starts from the morning at 06.30 WIB with the recitation of Al-Quran verses (Surah Al-Kahfi, Surah Yasin), and the traditional event of bathing Shafar then ends with eating together. 2) Tourism development in Atinggola District is quite good, seen from the policy of the District Government. North Gorontalo and 3) In implementing tourism development, the Tourism and Culture Office always tries to develop tourism in Atinggola District, namely by carrying out tourism promotion programs, tourism destination development programs and tourism partnership programs. The tourism promotion program is carried out by organizing the Shafar bathing ritual which is carried out once a year in addition to tourism promotion via the internet. While the tourism partnership program, the Tourism and Culture Office collaborates with several related agencies to help develop tourism in Atinggola District.
\end{abstract}

Key Word: Policy Implementation, Tourism, Shafar Bathing

\section{A. PENDAHULUAN}

Negara indonesia merupakan negara kepulauan, yang punya suku bangsa dan tradisi berbeda-beda dan tersebar di wilayah Indonesia khususnya tersebar di Pulau Sulawesi. Kata Tradisi yang di kutip oleh Muhaimin Funk dan Wagnalls bahwa sebagai pengetahuan, doktrin, kebiasaan, praktek dan lain-lain yang dipahami sebagai pengetahuan yang telah diwariskan secara turun-temurun termasuk cara penyampai doktrin dan praktek tersebut.(Ghoffir, 2001, p. 11) 


\section{TULISAN ILMIAH PARIMISATA}

Indonesia adalah Masyarakat sangat bermacam rupa yang sangat di kenal. Inilah yang menjadi semboyan Negara Republik Indonesia "bhineka tunggal ika" artinya "berbeda-beda tapi satu". Semboyan kesatuan Republik Indonesia merupakan arti dari berbagai macam suku, ras, bangsa akan tetapi satu dalam Indonesia. melihat masyarakat Indonesia yang terdiri dari berbagai suku bangsa, agama, ras yang beraneka ragam merupakan ciri khas masyarakat Indonesia, sehingga muncullah kebudayaan yang dianggap sebagai pedoman hidup dalam memenuhi kebutuhan sehari-hari baik secara jasmani maupun rohani.

Warisan budaya bangsa Indonesia, seperti halnya warisan budaya pada umumnya, dapat digolongkan atas benda yang dapat disentuh dan yang tak dapat disentuh. Semua itu dapat di golong kan atas (a) warisan masa lalu, dari sukusuku bangsa di Indonesia, dan (b) hasil karya masa kini' mulai sejak adanya kesatuan nasional Indonesia.

Strategi budaya yang diperlukan adalah yang mengarah kedua tujuan, yaitu pertama, tujuan adaptasi, dan kedua, tujuan pertahanan dan pelestarian. Strategi adaptasi diperlukan untuk senantiasa dapat menyesuaikan diri dengan perkembangan-perkembangan yang mempunyai daya berlaku secara global. Adaptasi yang diperlukan dalam hal ini adalah tidak hanya agar bangsa tidak ketinggalan dengan perkembangan kemajuan-kemajuan di dunia, melainkan lebihlebih adalah agar tidak semata-mata diserang dan ditelan oleh bangsa-bangsa lain.

Strategi pertahanan dan pelestarian dimulai dari upaya pengenalan dan pemahaman yang mendalam akan khazanah budaya bangsa sendiri, baik berupa konsep-konsep, nilai-nilai etika, serta teknologi. Bersama dengan upaya dan pemahaman itu diperlukan pula penanaman rasa menghargai, dan bahkan bangga dengan merasa memiliki, akan khazanah budaya sendiri. Lebih jauh pelestarian itupun memerlukan kreativitas untuk membentuk khazanah budaya tersebut tetap hidup dan relevan dengan kehidupan bangsa di masa kini.

Sementara dalam skala bangsa kebudayaan itu berkembang terus, masingmasing manusia warga bangsa itu secara individual, dari hari ke hari mengalami 


\section{TULISAN ILMIAH PARIMISATA}

suatu kehidupan, yang dengan disadarinya ataupun tidak, diarahkan oleh sebuah struktur budaya. Struktur budaya ini terbentuk oleh sistem nilai, sistim konsepkonsep dasar, serta sistim pola tingkah laku yang terkait dengan sistim sosial. kebanyakan warga masyarakat Indonesia adalah seorang dwi-budayawan. Di satu sisi ia adalah penganut kebudayaan suku bangsa, dalam tingkat kekentalan yang beraneka ragam, sedangkan di sisi lain ia juga penganut kebudayaan nasional Indonesia, juga pada tingkat penghayatan yang beraneka ragam.

Peran budaya pada bangsa dan negara sangatlah besar untuk pengembangan bangsa, untuk itu kebudayaan yang tersebar di berbagai daerah akan terus digali dan dikembangkan kebudayaannya, agar bisa mempersembahkan partisipasi untuk pembangunan nasional. Sebagai upaya memanifestasikan masyarakat yang adil dan sejahtera pemerintah indonesia harus mengembangkan kebudayaan daerah yang melambangkan sebuah implementasi budaya daerah, lebih khusus lagi kebudayaan yang bersifat religius. Kebudayaan dianut oleh masyarakat beranekaragam tersebar di seluruh wilayah nusantara salah satunya terdapat di Kecamatan Atinggola Kabupaten Gorontalo Utara Provinsi Gorontalo.

Desa Buata yang terdiri dari kawasan wisata Desa Buata adalah salah satu desa di Kabupaten Gorontalo Utara yang rutin melaksanakan kegiatan Mandi Shafar setiap tahunnya. Tradisi Mandi Shafar ini merupakan tradisi warisan yang nenek moyang penduduk asli Desa Buata bagian dari suku Gorontalo. Mandi Safar ini rutin diselenggarakan oleh masyarakat pada minggu terakhir bulan Shafar setiap tahunnya. Tradisi Mandi Shafar ini dihadiri dan diikuti oleh ratusan bahkan ribuan masyarakat yang berasal dari seluruh warga Desa Buata dan Masyarakat Desa disekitarnya bahkan banyak juga warga yang datang berasal dari luar Desa Buata tanpa ada batasan-batasan tertentu (usia, strata sosial, ekonomi, dan lain-lain). Tradisi ini dilakukan dengan beberapa tahapan, mulai dari persiapan, pelaksanaan dan penutupan. Pada tahap persiapan, masyarakat bermusyawarah dan bersama-sama mempersiapkan segala sesuatu yang 


\section{TULISAN ILMIAH PARIWISATA}

dibutuhkan dalam pelaksanaan tradisi mandi Shafar, mulai dari mempersiapkan tema kegiatan, peralatan, dan menentukan lokasi penyelenggaraan.

Mandi Shafar yang dilaksanakan pada tahapan-tahapan dan rangkaian pada penyelenggaraan Mandi Shafar memiliki makna dan nilai tersendiri bagi masyarakat Desa Buata. Umpamanya selalu melakukan musyawarah dan mufakat pada rangkaian persiapan ritual, kecintaan terhadap lingkungan selalu dijadikan simbol-simbol pada kegiatan ritual tersebut semisal pawai keliling yang dengan memperlihatkan simbol-simbol tertentu, serta do'a bersama menandakan nilai keimanan, ketakwaan dan permohonan pertolongan kepada Allah Swt. serta mandi bersama sebagai acara puncaknya menandakan penyucian diri dari segala akhlak tercela.

Mandi Shafar ini dilaksanakan di dua tempat yaitu untuk ritual tradisional di pusat kan di hulu sungai Andagile (Desa Buata) sementara untuk ritual mandi Shafar Nasional di tempatkan di muara Sungai Andagile. Masyarakat Desa Buata Kecamatan Atinggola penduduknya sebagian besar adalah agama islam selalu mempertahankan adat atau tradisi-tradisi keislaman seperti Mandi Shafar yang telah ada sejak lama. Desa Buata merupakan salah satu destinasi wisata unggulan di Kab. Gorontalo Utara, sehingga Tradisi Mandi Shafar akan dijadikan sebagai wahana edukasi kepada generasi muda untuk memperkenalkan kepada mereka nilai-nilai pendidikan islam agar generasi muda tidak kehilangan jati diri mereka di tengah perkembangan zaman yang semakin global dan di tengah rongrongan budaya luar (Barat).

Mandi Shafar adalah budaya ritual yang ada di Kecamatan Atinggola. Sesuai dengan namanya Mandi Shafar dilaksanakan pada hari Rabu, minggu terakhir di bulan Shafar setiap tahun. Keistimewaaan diangkat dalam kegiatan Ritual Mandi Shafar ini adalah masyarakat di Kecamatan Atinggola khususnya masyarakat Islam menganggap bahwa hari itu adalah hari istimewa untuk mencuci dari segala yang berhubungan dengan naas-naas diri, baik itu telah terjadi sebelum atau pun akan terjadi pada hari akan datang. Keistimewaan ini tentu menjadi 


\section{TULISAN ILMIAH PARIMISATA}

sebuah kebanggaan tersendiri bagi masyarakat Atinggola karena budaya ini hanya ada di Kecamatan Atinggola.

Keistemawaan yang ada pada masyarakat Atinggola melahirkan inisiatif untuk mengangkat budaya mandi Shafar kepermukaan, sehingga akan menjadi salah satu wisata budaya yang ada di Kabupaten Gorontalo Utara bahkan menjadi wisata budaya nasional. Namun yang terjadi setiap tahun pada perayaan budaya mandi Shafar ini pelaksanaannya selalu berubah-ubah dan berbeda. Budaya ritual Mandi Safar merupakan satu perayaan masyarakat Atinggola dan telah diwarisi oleh beberapa generasi. Ini diadakan setiap tahun apabila tiba bulan Shafar yaitu bulan kedua di dalam kalender Islam. Ia disambut pada hari Rabu yang terakhir dalam bulan tersebut.

Masyarakat menganggap bahwa bulan Shafar adalah termasuk bulan naas atau bulan bala karena di dalam bulan ini utamanya pada hari Rabu terakhir, masyarakat meyakini bahwa Allah banyak menurunkan bala kepada mahluk-Nya di dunia ini. Oleh karena itu orang-orang tua sering mengingatkan agar berhatihati ketika melakukan setiap pekerjaan. Tempat yang biasa menjadi basis pelaksanaan mandi Shafar ialah di bagian hulu sungai Andagile Desa Buata dan Muara sungai Andagile. Berbagai lapisan masyarakat ikut serta dalam kegiatan ini.

Artikel ini mengangkat berbagai masalah yaitu; 1) Seperti apa Proses Ritual Mandi Shafar di Kec. Atinggola Desa Buata Kabupaten Gorontalo Utara? 2) Bagaimana Implementasi Kebijakan Pemerintah Daerah dibidang Pariwisata Budaya terhadap Ritual Mandi Shafar di Kabupaten Gorontalo Utara?. Secara Akademis artikel ini diharapkan dapat memberikan gambaran sekaligus masukan mengenai kebijakan-kebijakan yang diambil pemerintah untuk memajukan sektor wisata khususnya wisata budaya yang ada di gorontalo Utara. Secara Praktis artikel ini dapat bermanfaat bagi pembaca dan pemerhati budaya untuk lebih dikembangkan lagi. 


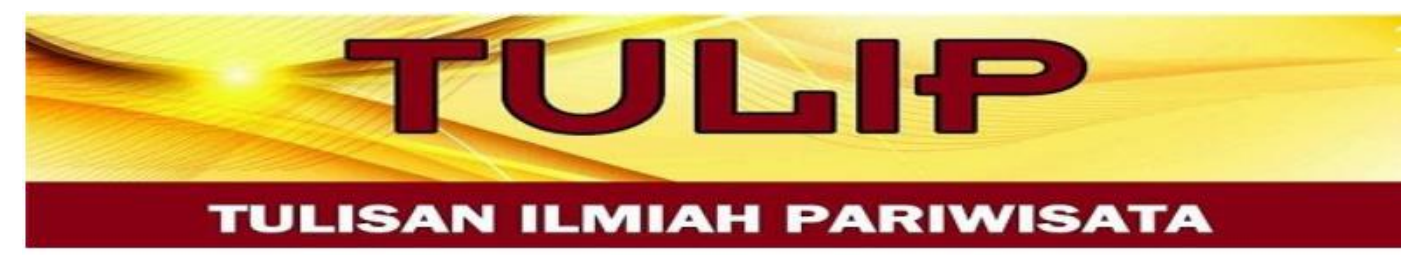

\section{B. METODOLOGI PENELITIAN}

Peneliti dalam penelitian ini menggunakan pendekatan kualitatif, hal ini disebabkan oleh karena data yang berkaitan bukan berupa angka tapi data yang peneliti peroleh di lapangan adalah data yang berupa informasi atau keterangan. Pendekatan kualitatif deskriptif yang peneliti gunakan pada penelitian ini. Penelitian deskriptif merupakan pengumpulan data secara deskriptif yang tidak harus menemukan atau menafsirkan antara hubungan, hipotesis, membuat ramalan, atau mendapatkan makna, dan implikasi walaupun penelitian yang bertujuan untuk menemukan hal-hal tersebut dapat mencakup juga metode deskriptif.(Suryabrata, 1983, p. 75). Model analisis yang digunakan dalam penelitian ini adalah model Interactif yang dikembangkan oleh Miles dan Huberman yang dimulai dengan pengumpulan data, reduksi data, penyajian data, dan penarikan kesimpulan/verifikasi. Proses analisis data dilakukan secara terus menerus di dalam proses pengumpulan data selama penelitian berlangsung. (Sugiono, 2005, p. 20)

\section{HASIL DAN PEMBAHASAN}

\section{a. Proses Ritual Mandi Shafar di Kabupaten Gorontalo Utara}

Ritual merupakan suatu bentuk atau perayaan (celebratian) yang berhubungan dengan beberapa kepercayaan atau agama dengan ditandai oleh sifat khusus, yang menimbulkan rasa hormat yang luhur dalam arti merupakan suatu pengalaman yang suci.(O`Dea, 1995, p. 5) sementara itu, Dalam tafsir lain, Shafar juga disebut bulan tiupan angin. Dari sudut pandang musim, dipandang kurang menguntungkan dan karenanya sejumlah aktifitas tidak dapat dilakukan secara maksimal. Barangkali dari kegagalan ini kebanyakan masyarakat menganggap bulan Shafar sebagai bulan penuh bala.

Pada pelaksanaan prosesi mandi Shafar diawali dengan penyambutan khalifah (bupati/camat) kabupaten dan kecamatan di depan pintu masuk dipandu oleh pemangku adat atau bate. Sepanjang perjalanan menuju bangsal ucapan- 


\section{TULISAN ILMIAH PARIMISATA}

ucapan bahasa adat oleh $w и$ 'u (pemangku adat setelah bate) menjadi penuntun langkah khalifah sambil dipayungi oleh pemangku adat. Khalifah sampai di tangga bangsal diterima oleh pemangku adat dan bate dan didampingi oleh tokoh agama, tokoh masyarakat serta para pegawai syara', kemudian mempersilahkan untuk duduk pada tempat yang telah disediakan.

Selanjutnya kegiatan prosesi ini dilakukan dengan adat seperti penyambutan para tamu penting yang ada di daerah Gorontalo lainnya. Kemudian dilanjutkan Dengan mandi bersama yang dipimpin oleh tokoh agama di depan daun penangkal/penawar (tobango) yang telah ditulis dengan niat mandi Shafar. Setelah mandi bersama melakukan ganti baju ditempat yang telah disiapkan dan kembali ke bangsal untuk berdoa bersama yang dipimpin oleh imam wilayah sebagai tokoh agama. Setelah berdoa di lanjutkan dengan kegiatan makan bersama.

Pada acara akhir pemangku adat menyampaikan sejarah singkat mandi Shafar serta maksud dan tujuan kegiatan ini dilaksanakan dan ditutup dengan ajakan menanam pohon (mahoni, jati, trembesi, meranti, glodokan tiang). Inilah sedikit uraian singkat prosesi mandi Shafar yang ada di Kecamatan Atinggola berlangsung setiap tahun. Kegiatan mandi Shafar adalah suatu ritual keagamaan bernuansa islami yang di anut oleh masyarakat kerajaan Atinggola sejak dulu hingga sekarang masih tetap di lestarikan sebagai budaya yang berkembang dan terpelihara. Sebagaimana pada bulan-bulan lainnya yang dikenal mempunyai hari-hari naas tertentu maka seperti itu pula pada bulan Shafar.

Hari naas di bulan Shafar ditetapkan yaitu adalah hari rabu. Naas maksudnya menjaga kemungkinan timbulnya kecelakaan pada diri pribadi seseorang/kaum bahkan alam pada satu hari penuh. Oleh karena itu pad hari naas tersebut diajukan mandi melafalkan niat meminta perlindungan dari Allah Swt untuk dihindarkan dari kecelakaan atau bencana. Walaupun celaka itu datang tanpa diketahui sebelumnya namun ikhtiar itu sedapat mungkin tidak dilalaikan. 


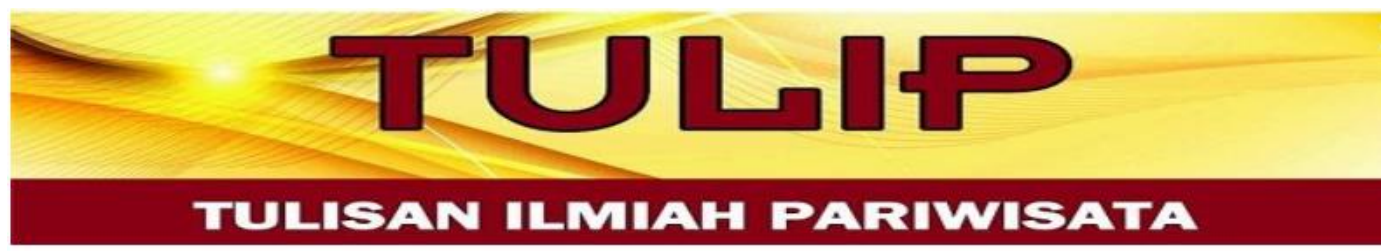

Adapun pelaksanaan mandi Shafar itu meliputi pembacaan ayat suci AlQuran seperti surat Al-Kahfi, surat Yassin. Berbarengan dengan pembacaan ayat-ayat tersebut, sebagainya melakukan mandi bersama dengan pakaian yang telah disiapkan sambil melafalkan niat sebagai berikut: Aku berniat mandi Shafar pada bulan Shafar di hari Rabu terakhir pada bulan ini untuk menolak bala dan minta dipelihara dari fitnah dajjal, keselamatan atas Nabi Ilyas dan keselamatan bagi kamu dan semoga kamu masuk kedalamnya (bulan Shafar) dengan kekal karena Allah Ta'ala. Bagi yang belum hafal lafal niat tersebut dapat menggunakan tulisan niat ini yang ditulis pada daun tobango (tobango) artinya "penangkal" diikatkan pada sepotong kayu pada posisi ditancapkan di depan orang yang sedang mandi melawan arus air sungai. Setelah acara mandi selesai dilanjutkan dengan makan bersama sajian berbagai macam hidangan masakan yang telah siap untuk disantap. Mandi Shafar menurut tata cara para pendahulu/leluhur yaitu kegiatannya yang dilakukan di hulu sungai dengan tujuan agar bencana dan mala petaka ikut bersama terbawa oleh aliran air sungai. Ritual ini semata mata hanyalah merupakan perlakuan atas permohonan dan doa yang dihadapkan kepada yang Maha Kuasa, agar manusia, alam dan makhluk hidup pada umumnya dapat terhindar dari bencana dan petaka, kemudian berganti berkah dan rahmat menyertai setiap langkah kehidupan umat. Budaya mandi Shafar ini terus berkembang sehingga pelaksanaannya menyebar dan dilakukan secara bersamaan di pinggiran sungai di setiap desa.

Sehari sebelum pelaksanaan mandi Shafar, warga berdatangan satu persatu ke muara sungai Andagile. muara sungai Andagile memiliki pemandangan yang indah. Kemudian warga yang sudah berdatangan mendirikan tenda untuk bermalam. Selepas shalat Isya warga masyarakat melaksanakan zikir bersama di sekitar sungai dan ini menandakan bahwa awal untuk ritual mandi Shafar telah di mulai.

Mandi Shafar ini dilaksanakan di dua tempat yaitu untuk ritual tradisional di pusat kan di hulu sungai Andagile (Desa Buata) sementara untuk ritual mandi 


\section{TULISAN ILMIAH PARIMISATA}

Shafar Nasional di tempatkan di muara Sungai Andagile yaitu di Desa Buata. Kini ritual tersebut tidak hanya menjadi Tradisi saja namun juga telah menjadi festival yang setiap tahunnya selalu meriah. Masyarakat berharap kepada Pemda untuk menjadikan tradisi ini sebagai ikon pariwisata, yang ada di Gorontalo Utara, mealui kebijakan-kebijakan dari pemerintah itu sendiri sehingga akan tercipta ikon wisata budaya yang dilaksanakan setiap tahun di provinsi Gorontalo lebih khusus di Kab. Gorontalo Utara.

Berikut ini adalah urutan pelaksanaan kegiatan budaya ritual Mandi Shafar yang dapat dikatakan mengandung nilai-nilai pelestarian sejarah, lingkungan dan budaya yaitu adalah sebagai berikut:

1. Pada pagi sekitar jam 06.30 wita warga masyarakat yang dipimpin oleh tokoh agama membaca Kitab Suci Al-Quran, Surah Al-Kahfi, Surah Yasin.

2. Pada saat khalifah negeri tiba ditempat (zaman dulu adalah Raja Atinggola tapi sekarang pemerintah kecamatan/daerah) disambut dengan adat dan di bawa sampai ke tempat berdoa dengan bahasa adat.

3. Setelah khalifah tiba maka pemangku adat memberitahukan kepada seluruh warga masyarakat bahwa khalifah sudah tiba ditempat. (Pada setiap antara urutan kegiatan satu dengan lainnya diawali atau ditutup dengan pemberitahuan kepada khalifah dan dilakukan sesuai adat).

4. Pemangku adat meletakkan tempat pinang dan tempat sirih di depan khalifah sebagai wujud penyambutan secara budaya Atinggola, kemudian oleh pemangku adat dengan isyarat kepada khalifah bahwa pinang dan sirih itu disentuh.

5. Kemudian khalifah disuguhkan air putih di atas baki dan kue/buah-buahan serta meminta kepada khalifah agar air serta buah-buahan tersebut disentuh.

6. Kemudian 2 orang gadis dan seorang nenek memakai kebaya mengambil air di sungai dengan menggunakan 2 potong bambu berwarna kuning yang 


\section{TULISAN ILMIAH PARIMISATA}

berukuran 25 sampai $30 \mathrm{~cm}$ yang diatasnya sudah diletakkan bunga mayana, urutan kegiatan ini dipandu bahasa adat oleh panitia yang telah ditunjuk. Bahasa adat yang disampaikan tersebut seperti berikut ini Ya Allah, kami minta kepadamu air berkah ini untuk dijadikan air hidayah darimu, dipersembahkan bagi khalifah serta seluruh warga Atinggola sebagai penanda budaya mandi Shafar tahun ini semoga beroleh rahmat$\mathrm{Mu}$.

7. Setelah ke 2 gadis dan nenek tersebut kembali dari sungai, maka air tersebut dituangkan kedalam wadah yang sudah terisi lebih dulu dengan bunga polohungo yang sudah diiris-iris.

8. Pemangku adat mencelupkan seikat bunga mayana ke dalam loyang tadi, kemudian dipercik-kan kepada khalifah dan tamu yang hadir. Sambil membaca Ya Allah, ini adalah air yang penuh berkah darimu. Air ini adalah air rahmat-Mu, seperti air hujan yang Engkau turunkan dari langit membasahi bumi yang dapat menghidupkan segala tanaman di alam ini, air Engkau titipkan di alam ini untuk selalu kami jaga agar alam selalu nyaman dan lestari, air yang dapat memberikan kedamaian yang hidup di alam kepunyaan-Mu ini, air yang mendatangkan kesejukan dan ketenangan hati. Melalui kebesaran-Mu dan zat-Mu yang agung air ini menggambarkan sifat-Mu selalu mengalir dari atas kebawah. Maka jadikan khalifah atau raja pemimpin kami untuk selalu menaungi dan melindungi rakyatnya. Ya Allah jadikan Alam yang kami tempati ini jauh dari kerusakan atau bencana, suburkan semua tanaman di alam ini, Ya Allah lindungi dan berkahilah negeri ini Amin.

9. Dua orang gadis dan nenek membuang pembungkus makanan serta kulit buah-buahan ke sungai, sebagai syarat menolak bala bila ada pada makanan yang telah dimakan maupun yang akan dimakan setahun kedepan yang tidak memiliki berkah dari Allah. Kemudian pembungkus makanan dan kulit buah-buahan tadi diangkat keatas bantaran sungai 


\section{TULISAN ILMIAH PARIMISATA}

untuk dikeringkan dan dibakar dengan tujuan agar tidak mencemari aliran sungai.

10. Pemberitahuan pembacaan doa.

11. Doa permohonan kepada Allah SWT yang di pimpin oleh tokoh agama/imam wilayah yang intinya memohon rezeki yang melimpah ruah, memohon kesehatan bagi seluruh warga, doa tolak bala/musibah/bencana.

12. Setelah doa selesai dilanjutkan dengan penyampaian rezeki dan rasa syukur warga yang diserahkan kepada khalifah dalam bentuk sedekah.

13. Pemberitahuan untuk mandi bersama.

14. Mandi bersama dipimpin oleh imam dengan niat mandi Shafar, selanjutnya mandi bersama seluruh warga.

15. Setelah mandi bersama mengganti pakaian ditempat yang telah disiapkan oleh panitia.

16. Kemudian dilanjutkan makan bersama.

17. Setelah makan bersama pemberitahuan bahwa rangkaian kegiatan budaya ritual mandi Shafar beserta doa telah selesai kepada khalifah dengan bahasa adat.

\section{b. Implementasi Kebijakan Pemerintah Daerah dibidang Pariwisata Budaya terhadap Ritual Mandi Shafar di Kabupaten Gorontalo Utara}

William Dunn menjelaskan analisis kebijakan adalah aktivitas intelektual dan praktis yang ditunjukkan untuk menciptakan, secara kritis menilai, dan mengkomunikasikan pengetahuan tentang dan dalam proses kebijakan.(Nugroho, 2007, p. 7) Definisi analisis kebijakan dari Walter William adalah sebuah cara penyintesisan informasi termasuk hasil-hasil penelitian, untuk menghasilkan format keputusan kebijakan (yang ditentukan dari sejumlah alternatif pilihan) dan menentukan informasi yang relevan dengan kebijakan.(Nugroho, 2007, p. 36) Sedangkan menurut Thomas R. Dye, analisis kebijakan adalah penyebab capaian 


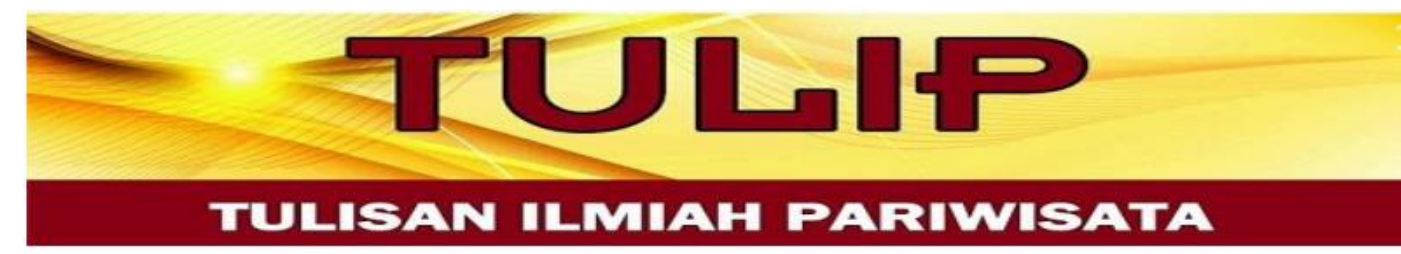

hasil yang berbeda-beda, mengapa melakukannya, dan apa sesungguhnya yang dilakukan. (Wahab, 2011, p. 4)

Dapat disarikan bahwa analisis kebijakan adalah sebuah cara penuntasan dari hasil penciptaan format keputusan kebijakan untuk hasil dan informasi penelitian, dalam proses kebijakan secara kritis penilaian, adalah pengkomunikasian pengetahuan dan menentukan informasi yang relevan. Hasil (oucome), sasaran, tujuan, prioritas, dan strategis merupakan gambaran kebijakan yang sangat esensi yang diharapkan. Dibutuhkan instrument/alat kebijakan (policy tools/ instruments) untuk kebijakan bisa berfungsih dengan baik. Jadi, instrumen kebijakan adalah tindakan atau seperangkat tindakan yang merupakan realisasi dari pemerintah sebagai upaya kebijakan yang ditetapkan. Menurut Tatang A. Taufik setiap (atau kombinasi beberapa) instrumen kebijakan biasanya melibatkan (mengandung) setidaknya 3 (tiga) aspek, yaitu: 1) piranti hukum menyangkut aspek legal/hukum yang mendukungnya (melandasi-nya); 2) tatanan kelembagaan berkaitan dengan tatanan lembaga (organisasi) yang terlibat, fungsi/peran dan pengorganisasian (struktur dan hubungan atau interaksi antar aktor); 3) mekanisme operasional berkaitan dengan pola, cara/metode dan prosedur serta proses pelaksanaan dalam implementasi praktis. Selain itu, hal yang juga penting dipertimbangkan berkaitan dengan perancangan instrument kebijakan adalah tatanan sosial (social arrangement) bagi konteks kebijakan tersebut.(Taufik, n.d.)

Dengan adanya analisis kebijakan tersebut, dalam penelitian ini menggunakan instrumen kebijakan yaitu: piranti hukum, tatanan kelembagaan, dan mekanisme operasional. Berdasarkan teori menurut Tatang A. Taufik instrumen kebijakan memiliki tiga hal, yakni: piranti hukum, tatanan kelembagaan, dan mekanisme operasional.(Taufik, n.d.). Untuk itu disajikan mengenai ketiga instrumen tersebut dalam kaitannya dengan analisis kebijakan Pemerintah dibidang Pariwisata Budaya terhadap Tradisi Mandi Shafar di Kabupaten Gorontalo Utara.

Piranti hukum merupakan aspek legal/hukum yang mendukungnya (melandasinya). Kebijakan pengembangan pariwisata sangat penting dalam 


\section{TULISAN ILMIAH PARIWISATA}

meningkatkan perkembangan pariwisata terutama di Kecamatan Atinggola yang memiliki banyak potensi wisata. Dengan adanya kebijakan pengembangan pariwisata, pemerintah dituntut untuk ikut berpartisipasi dalam mengembangkan potensi pariwisata. Namun, kebijakan pengembangan pariwisata di Kabupaten Gorontalo Utara belum ada sehingga kegiatan pengembangan pariwisata belum berjalan secara maksimal. Pengembangan pariwisata dilakukan Dinas Pariwisata dan Kebudayaan dengan membentuk program-program pengembangan pariwisata yang didasarkan pada tugas pokok dan fungsi Dinas Pariwisata dan Kebudayaan yang diatur dalam Peraturan Bupati Gorontalo Utara Nomor 34 Tahun 2016 tentang Tugas Pokok dan Fungsi Dinas Pariwisata dan Kebudayaan Kabupaten Gorontalo Utara. Hal tersebut sebagaimana dimaksud dalam pasal 11 ayat $3 \mathrm{a}$ bahwa : Bidang industri dan destinasi pariwisata dalam melaksanakan tugas dimaksud pada ayat (20 menyelenggarakan fungsi ; a) menyusun rumusan kebijakan di pengembangan infrastruktur dan bina peran masyarakat, pengembangan destinasi pariwisata dan sarana usaha dan jasa pariwisata.(Peraturan Bupati Gorontalo Utara No. 34 Tahun 2016 Tentang Kedudukan, Susunan Organisasi, Tugas, Fungsi Dan Tata Kerja Dinas Pariwisata Dan Kebudayaan, n.d.)

Program yang dilakukan Dinas Pariwisata dan Kebudayaan untuk mendukung pelaksanaan pengembangan pariwisata yang ada di Kecamatan Atinggola adalah program promosi pariwisata, program pengembangan destinasi pariwisata dan program kemitraan pariwisata. Penyelenggaraan Ritual mandi Shafar adalah salah satu bentuk kegiatan promosi pariwisata yang dilakukan oleh Dinas Pariwisata dan Kebudayaan dalam mengembangkan pariwisata yang ada di Kecamatan Atinggola. Akan tetapi hal tersebut kurang maksimal hal ini disebabkan oleh beberapa faktor antara lain adalah tidak berjalannya kebijakan pemerintah daerah untuk memjukan program destinasi wisata yang ada di Kab. Gorontalo Utara, sehingga kegiatan ritual mandi Shafar hanya sebagai ajang momen tahunan yang dilaksanakan oleh pemerintah setempat dan bukan sebagai 


\section{TULISAN ILMIAH PARIMISATA}

destinasi wisata yang bisa menjadikan sebagai wisata sejarah untuk menarik wisata asing mengenal lebih jauh tentang sejarah ritual mandi Shafar tersebut.

Tatanan kelembagaan berkaitan dengan tatanan lembaga (organisasi) yang terlibat, fungsi/peran dan pengorganisasian (struktur dan hubungan atau interaksi antar aktor). Pengembangan pariwisata bisa berjalan lebih baik maka dibutuhkan pelaksanaan kebijakan pengembangan pariwisata pada kelembagaan adalah salah satu ukuran yang paling penting. Sebagai motor penggerak pemerintah sangat dibutuhkan agar pengembangan dan pembangunan sektor pariwisata akan lebih maju dengan melibatkan berbagai sektor atau pihak yang berlatar belakang pariwisata.

Peran Pemerintah Kabupaten Gorontalo Utara dalam pengembangan pariwisata sudah mulai ikut untuk berpartisipasi. Peran Pemerintah Kabupaten Gorontalo Utara adalah dengan meningkatkan kerjasama dengan instansi-instansi terkait, stakeholder, dan masyarakat setempat serta mempromosikan pariwisata melalui seminar-seminar. Pada pelaksanaan kegiatan pengembangan pariwisata, sebagai pengelola pariwisata, Dinas Pariwisata dan Kebudayaan harus menjalin kerjasama dan komunikasi yang baik antar sesama pegawai. Kerjasama dan komunikasi antar pegawai sudah terjalin dengan baik karena adanya pembinaan dan pelatihan, dibuktikan dengan keikutsertaan seluruh pegawai dalam acara yang diadakan oleh Dinas Pariwisata dan Kebudayaan dalam pengembangan pariwisata.

Dari penjelasan tersebut, dapat disarikan bahwa tatanan kelembagaan dalam pelaksanaan kegiatan pengembangan pariwisata di Kecamatan Atinggola meliputi peran Pemerintah Kabupaten Gorontalo Utara dan hubungan kerjasama dan komunikasi antar pegawai harus berjalan dengan baik.

Mekanisme operasional (operational mechanism) berkaitan dengan pola, cara/metode dan prosedur serta proses pelaksanaan dalam implementasi praktis. Pelaksanaan kegiatan pengembangan pariwisata dilaksanakan secara manual yang dilakukan oleh masyarakat dengan mengelola beberapa obyek wisata, sedangkan 


\section{TULISAN ILMIAH PARIMISATA}

Dinas Pariwisata dan Kebudayaan melakukan kerjasama dengan berbagai instansi-instansi terkait serta mempromosikan potensi pariwisata yang ada di Kecamatan Atinggola baik tingkat regional maupun nasional melalui seminarseminar maupun internet. Dengan adanya kegiatan pengembangan pariwisata di Kecamatan Atinggola perkembangan pariwisata di Kecamatan Atinggola terutama wisata alamnya mengalami kenaikan cukup berarti dari sisi kesadaran masyarakat akan berwisata sehingga jumlah pengunjung pariwisata meningkat terutama pada hari libur.

Dari penjelasan tersebut, dapat disarikan bahwa pelaksanaan pengembangan pariwisata dilakukan oleh masyarakat dan Dinas Pariwisata dan Kebudayaan. Pengelolaan beberapa objek wisata dilakukan oleh masyarakat, sedangkan kerjasama dengan berbagai instansi-instansi terkait serta mempromosikan potensi pariwisata melalui seminar-seminar maupun internet dilakukan oleh Dinas Pariwisata dan Kebudayaan.

Pertimbangan dengan perancangan instrument kebijakan adalah Tatanan sosial yang penting dipertimbangkan. untuk mengembangkan dan membangun pariwisata, diperlukan dukungan dari berbagai pihak baik pemerintah, swasta maupun masyarakat. Partisipasi masyarakat mempunyai peran yang sangat penting dalam menunjang pembangunan pariwisata.

Partisipasi masyarakat di Kecamatan Atinggola dalam pengembangan pariwisata sudah mulai aktif, dibuktikan dengan adanya tempat wisata yang mulai ramai dengan pengunjung mulai dari wisata bahari dan wisata lainnya terutama wisata budaya yang setiap tahun mulai ramai dan memiliki ciri khas tersendiri terhadap makna dari ritual budaya mandi Shafar.

Dalam pelaksanaan pengembangan pariwisata dibutuhkan partisipasi dari stakeholder pariwisata. Stakeholder adalah kelompok atau individu yang dapat mempengaruhi dan atau dipengaruhi oleh suatu pencapaian tujuan tertentu. Partisipasi stakeholder adalah dengan mengelola beberapa obyek wisata yang ada di Kecamatan Atinggola serta membantu mempromosikan potensi wisata yang 


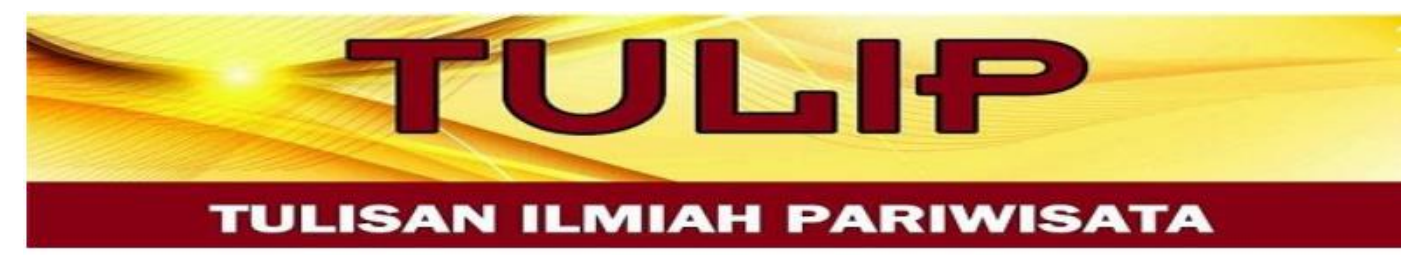

ada. Stakeholder pariwisata yang membantu mempromosikan potensi wisata yang ada di Kecamatan Atinggola adalah travel agent dan Pemerintah Desa. Sedangkan yang membantu mengelola beberapa obyek wisata adalah karang taruna.

Dari penjelasan tersebut dapat disarikan bahwa masyarakat Kecamatan Atinggola mulai berpartisipasi aktif dalam pengembangan pariwisata dengan adanya beberapa objek wisata yang dikelola masyarakat dan pemerintah Desa. Sedangkan stakeholder pariwisata membantu mempromosikan potensi wisata yang ada dan juga ikut membantu mengelola beberapa objek wisata.

\section{PENUTUP}

Setelah melakukan analisa dan interpretasi pada bab sebelumnya, peneliti akan menyajikan kesimpulan dan saran dari artikel berdasarkan hasil temuan data di lapangan, maka dapat diambil kesimpulan sebagai berikut: 1) Ritual mandi Shafar dimulai dari pagi hari yakni pukul 06.30 wita dengan pembacaan ayat-ayat Al-qur'an (Surah Al-Kahfi, Surah Yasin), kemudian penyambutan khalifah yang dalam hal ini Pemerintah setempat dan disambut dengan acara adat Kemudian 2 orang gadis dan seorang nenek memakai kebaya mengambil air di sungai dengan menggunakan 2 potong bambu berwarna kuning yang berukuran 25 sampai $30 \mathrm{~cm}$ yang diatasnya sudah diletakkan bunga mayana Setelah ke 2 gadis dan nenek tersebut kembali dari sungai, maka air tersebut dituangkan kedalam wadah yang sudah terisi lebih dulu dengan bunga polohungo yang sudah diiris-iris, dan Pemangku adat mencelupkan seikat bunga mayana ke dalam loyang tadi, kemudian dipercik-kan kepada khalifah dan tamu yang hadir dan berdoa. Setelah kegiatan adat dan berdoa selesai maka diakhiri dengan makan bersama dan selanjutnya mandi bersama di sungai Andagile. 2) Dilihat dari sudut pandang teori dengan menggunakan 3 instrumen yaitu piranti hukum, tatanan kelembagaan dan mekanisme operasional dapat disimpulkan bahwa pengembangan pariwisata di Kecamatan Atinggola sudah cukup baik; 3) Dalam pelaksanaan pengembangan pariwisata, Dinas Pariwisata dan Kebudayaan selalu berusaha dalam 


\section{TULISAN ILMIAH PARIMISATA}

mengembangkan pariwisata di Kecamatan Atinggola yaitu dengan melakukan program promosi pariwisata, program pengembangan destinasi pariwisata dan program kemitraan pariwisata. Program promosi pariwisata dilakukan dengan penyelenggaraan Ritual mandi Shafar yang dilaksanakan setiap setahun sekali selain promosi pariwisata melalui internet. Sedangkan program kemitraan pariwisata, Dinas Pariwisata dan Kebudayaan melakukan kerjasama dengan beberapa instansi terkait untuk membantu mengembangkan pariwisata di Kecamatan Atinggola.

\section{DAFTAR PUSTAKA}

Ghoffir, M. A. (2001). Islam Dalam Bingkai Budaya Lokal: Potret Dari Cirebon. Ciputat: PT. Logos Wacana Ilmu.

Nugroho, R. D. (2007). Analisis Kebijakan. Jakarta: Gramedia.

O`Dea, T. F. (1995). Sosiologi Agama: Suatu Pengenalan Awal. Jakarta: PT Raja Grafindo Persada.

Peraturan Bupati Gorontalo Utara No. 34 tahun 2016 Tentang Kedudukan,

Susunan Organisasi, Tugas, Fungsi dan Tata Kerja Dinas Pariwisata dan Kebudayaan.

Sugiono, M. dan H. dalam. (2005). Memahami Penelitian Kualitatif. Bandung: Alfabeta.

Suryabrata, S. (1983). Metodologi Penelitian. Jakarta: PT Rajagraffindo Persada.

Taufik, T. A. (n.d.). Pengembangan Sistem Inovasi Daerah: Perspektif Kebijakan. Jakarta : Pusat Pengkajian Kebijakan Teknologi Pengembangan Unggulan Daerah dan Peningkatan Kapasitas Masyarakat.

Wahab, S. A. (2011). Pengantar Analisis Kebijakan Publik. Malang: UMM Press. 